\title{
NANOSTRUCTURAL BIOCHEMICAL MODIFICATION OF FLAX FIBER IN THE PROCESSES OF ITS PREPARATION FOR SPINNING
}

\author{
Sergey Koksharov ${ }^{1,2}$, Svetlana Aleeva $^{2}$, Olga Lepilova ${ }^{2}$ \\ 1 Textile institute of Ivanovo State Politechnical University, Department of Technology ready-made garments \\ Russia Sheremetevsky prospekt 21, 153000 Ivanovo, e-mail: ksa@isc-ras.ru \\ ${ }^{2}$ G.A. Krestov Institute of Solution Chemistry of RAS, Laboratory Chemistry and technology of non-linear processes \\ Russia Akademicheskaya St. 1, 153045 Ivanovo; e-mail: sva@isc-ras.ru
}

\begin{abstract}
:
The elaborated principles of nanoengineering of linen textile materials implement the techniques of spatially localized effects of protein catalysts on polymeric cellulose companions with selective splitting of impurity compounds without damaging technologically necessary nano-sized formations of binders in the fiber structure. The ranges of optimal values of the residual content in flax fiber prepared for spinning are identified on the basis of the analysis of the successive stages of enzymatic and peroxide treatments contribution to the breakdown of polymers and the differentiation of the influence of impurities on the yarn technological properties. The recommended level of residual pectin, lignin and hemicellulose (wt. \%) is: after enzymatic treatment $P_{1}=1,0 \pm 0,1 ; L_{1}=3,9 \pm 0,3 ; H c_{1}=11,0 \pm 1,0$; after peroxide bleaching $P_{2}=0,4 \pm 0,05 ; L_{2}=2,3 \pm 0,3 ; H c_{2}=7,5 \pm 0,5$. The required level of fiber structural modification at the stage of preparing roving for spinning can be achieved through use of protein catalysts whose globule size is $50 \ldots 100 \mathrm{~nm}$. The use of enzymes with these dimensional characteristics helps to ensure breaking of polymer adhesives on the surface of incrusts and in the areas of intercellular formations, which hinder fiber crushing, without damaging nano-sized binding fractions. The implementation of this method contributes to a significant improvement in the uniformity of structural and physical and mechanical properties of flax yarn. Increase in yarn fineness and strength properties of semi-finished products, as well as improvement of deformation properties and reduction of yarn breakages during the spinning processes are achieved.
\end{abstract}

\section{Keywords:}

Flax fiber materials, polymer composition, enzymatic treatment, nanoengineering.

\section{Introduction}

In the textile industry, flax fibrous materials are processed in the form of complex fibers fragmented through-thickness, since elementary flax fiber has a smooth spindle-shaped surface and, unlike wool or cotton, has no adhesion ability. The processes of preparation of flax fiber at the stage of spinning are aimed at ensuring uniform crushing of bast bundles into groups of fibers having optimal thickness and length. It represents a difficult technological task that can be solved through multi-stage and long-term actions. For this purpose, mechanical methods of splitting and stretching of fibrous semi-finished products (combing) are used in addition to partial chemical cleavage of cellulose companions, first during preparation of roving for spinning and then during woven fabrics bleaching and finishing cycles.

One of the promising innovative directions in the production of fibrous materials is using enzymatic catalysis not only for selective action on certain types of polymer cellulose companions, but also for implementation of methods of textile semi-finished products nano-structural modification.

The original approaches are based on the fact that actions of nano-sized catalytic protein molecules are spatially limited within certain structural areas of the fibrous matrix. This principle forms the basis for technologies of cotton bioscouring $[1,2]$, with impact on the surface layer of the primary cell wall of the fiber, and wool processing $[3,4]$ through selective splitting of proteins of epicuticle by special form of enzymes (keratinases) enriched in sulfur-containing amino acid (cysteine). Linen production has the widest opportunities for the implementation of biochemical methods of nanoengineering. It can be explained by the peculiarities in the morphology of flax fiber materials. Flax fiber is a multicomponent polymer system with multilayer organization and, due to this fact, is a perfect object for the implementation of techniques of spatially localized modification through rational biocatalysed splitting of binders in the structure of flax complexes.

Major efforts have been carried out to improve and optimize of the enzymatic retting of flax which is a raw for textile industry. These efforts have been documented in numerous papers [5-8] and in the book The Biology and Processing of Flax [9]. Enzymatic scouring of linen fabric with use biopreparations for example Bioprep, Flaxzyme from Novozymes (North America) $[10,11]$ and other analogs $[12,13]$ is insufficiently described. New approaches to the development of a biochemical pretreatment process, leading to an improvement of the finishing technology through its unification, are formulated in Russia. for example 
simplified, uniform, two-stage production schemes for cotton, half-flax, flax/cotton and flax fabrics have been developed in the publishing [14].

A significant step towards identifying key components of multienzyme systems ensuring the achievement of effects of maceration during the preparation of flax roving for wet spinning is made by the staff of the Laboratory of Biotechnology and Corporate R\&D (Italy). On the basis of differentiated assessment of the influence of enzymes of various substrate activity it is shown [15] that the effect of the biocatalyst should be aimed at the destruction of, first of all, pectic compounds which are adhesive base of binders in the structure of the flax fibers. Moreover, it is logical to assume that a certain level of connectedness of elementary fibers should be saved. The rational construction of technological processes of textile production involves the dosed removal of impurities. However, up to date there are no precise recommendations concerning types of polymers subject to compulsory break-down in order to achieve improvement of fiber spinning properties, and extent of their extraction. In this regard, the data relating to the optimal level of polymer content in linen fiber at the time of spinning, their distribution between the structural formations of binders in complex fiber and non-cellulosic components impact on the totality of the technological characteristics of textile semifinished products are of great importance. It is especially important for rational elaboration of technologies of enzymatic processing of flax textile semi-finished products. The theoretical part of the paper reviews current concepts concerning specific features of the complex flax fiber structure necessary for the understanding of the advantages of enzymatic catalysis during textile materials preparation.

\section{Theoretical part}

When describing the chemical composition of flax fiber, it should be noted that its main components are cellulose $(65,2 \ldots 72,2 \%)$, hemicellulose $(17,110,1 \%)$, lignin $(2,37,7$ $\%)$, pectic substances $(2,8 \ldots 5,6 \%)$, nitrogenous substances $(1,9 \ldots 2,1 \%)$ and waxy substances $(2,23,0 \%)$. According to the widespread opinion concerning the morphological structure of bast-fiber materials, elementary fibers are united into bundles using layers that are generally referred to as «middle lamella» [16, 17]. Moreover, in biology of plants, binding substances in plant tissues are traditionally divided into grades depending on massiveness of their deposits $[17,18]$. Figure 1a shows that middle lamella (1) is a thin layer cementing together adjacent plant cells. But there are also larger formations that bind together several plant cells (2). Such structural fragments are referred to as intercellular formations. In case of rounded shape of the cross section of the cells, the areas of middle lamella have small width and the majority of binders are located in areas of intercellular formations. Structural zones (1) and (2) differ from each other not only by geometric parameters, but also by the structure of their polymers. The composition of middle lamella, as a rule, is determined by the components of the cell wall, but does not contain cellulose. Intercellular formations are characterized by a higher amorphousness, because polysaccharides in their composition have more branched structure.

These concepts can be fully applied to the description of the structure of bast flax bundles. The pictures of their cross sections (see Figure 1b) demonstrate that the faceted surface of the elementary fibers predetermines a considerable width of the zones of firm adherence of adjacent cells - middle lamellae $\left(1^{*}\right)$. At the same time, the irregularity of the fiber section, especially in the areas of their sharp ends, predetermines the presence of larger intercellular formations of binders $\left(2^{*}\right)$.

Taking into account the differences of geometrical parameters and polymer filling, the structural formations of binders in flax complexes can be divided in six types. Their dislocation is shown in the scheme of the bast bundle longitudinal section (see Figure 2).

The group of technologically valuable nanosized non-cellulosic polymer formations, which should be maximally saved in the processes of preparing flax roving for spinning, includes the following structural components of complex flax fiber:

Middle lamellae formed mainly by macromolecules of high-methoxylated pectic substances and less branched hemicelluloses; their thickness does not exceed $100 \mathrm{~nm}$. They predetermine the strength of the adhesive bond between elementary fibers during the process of industrial fiber crushing.

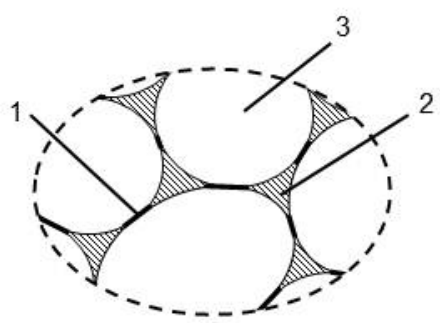

a)

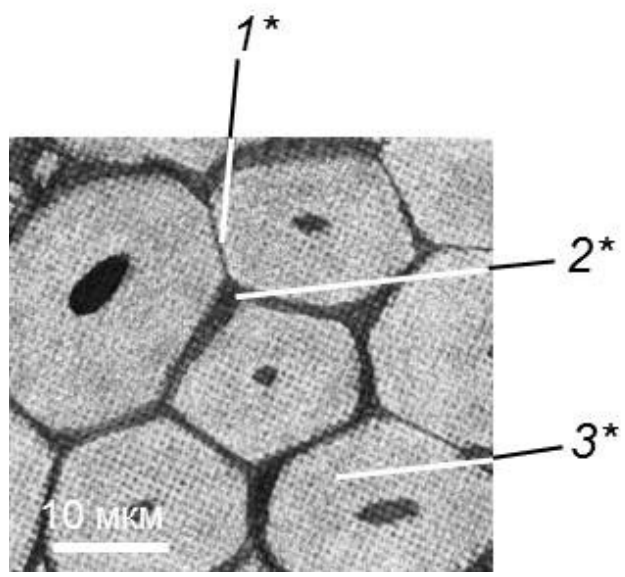

Figure 1. The scheme of cell connections in the structure of plants (a) and a picture of the cross section of bast flax bundle (b) $1,1^{*}-$ middle lamella; 2, 2* - intercellular formations; $3,3^{*}$ - plant cells. 


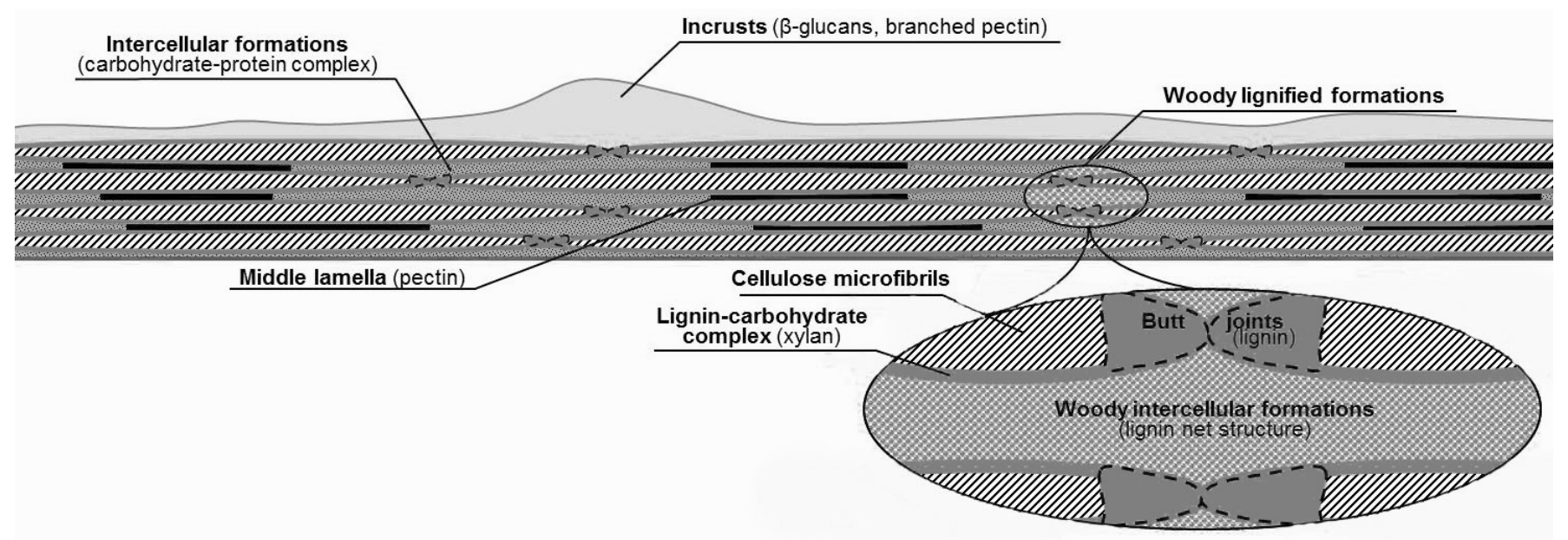

Figure 2. Chemical and morphological structure of complex flax fiber The ranking of non-cellulosic formations by size allows distributing them in two groups: micrometer and nanosized formations. Moreover, technologically the first group of binders hinders the processing of fibrous materials in the textile industry, and the second group has a number of positive functions.

Butt joints of elementary fibers formed by lignin contained in sharp ends of the plant cells. They ensure longitudinal adhesion of elementary fibers during the process of complex fiber crushing.

Lignin-carbohydrate complex of the cell wall formed by lightly crosslinked structures of lignin with hemicelluloses (mainly on the basis of $\beta$-glucans) and pectin, which bind together cellulose macrofibrils in the elementary fibers. This complex ensures amorphousness and flexibility of elementary fibers as well as quality of the yarn twisting.

The group of larger structural fragments includes the formations of impurities, whose size is comparable to the cross-sectional dimension of the elementary fibers and can be up to $15 \mu \mathrm{m}$. They hinder the spinning process. In this regard, during the processes of fiber preparation for spinning it is necessary to perform as complete splitting of such formations as possible. Along with intercellular formations of binders, this group includes:

- incrusts which are the residues of parenchymal tissues of the flax stem. They are located on the surface of the broken bast bundles either as a continuous layer (see Figure 3a), or as fragments (see Figure $3 b$ ) and bind together large groups of elementary fibers.

- woody lignified formations which represent autonomous polymer areas located in intercellular formations. Color reactions are widely used for their detection. For example, they give purple-red staining (see Figure $3 c$ ) in reactions with hydrochloric acid solution of phloroglucin (reagent of Wiesner).

Incrusts and intercellular formations are heteropolymeric systems containing pectic substances, neutral branched polysaccharides (first of all, $\beta$-glucan, galactomannan, glucomannan, etc) and glycoproteins, ensuring chemical crosslinking with the functional groups of pectins in the carbohydrateprotein complex. A part of intercellular formations contains lignin growing from butt joints in the form of tightly cross-linked netting structures (woody lignified formations). The presence of such structures significantly deteriorates the processing of fiber during spinning, increases breakage and yarn irregularity as well as hinders obtaining the required degree of whiteness and softness of the woven fabrics. The proportion of woody lignified formations increases in fibrous bundles of root part of flax stem and significantly increases in case of late flax pulling.

The removal of incrusts and intercellular formations is an important part of the process of industrial fiber preparation for spinning to ensure breakability of complex fiber, increase in yarn structural uniformity and reduction of its breakage. Meanwhile, the search of approaches of rational splitting of these fractions binders (adhesive materials) without damaging middle lamellae is a challenging task. In particular, the authors of this work [19] present results of microscopic study of the surface of bast bundles under chemical and enzymatic influences. The research has showed that traditional methods of chemical treatment do not allow destroying incrusts without loss of fiber spinnig properties. Difficulties arise due to the fact that chemical agents provoke the degradation of polymers in all structural fiber areas and do not allow performing the

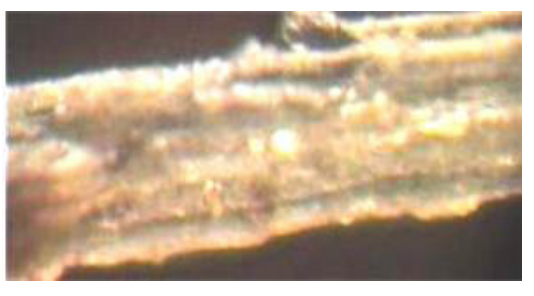

(a)

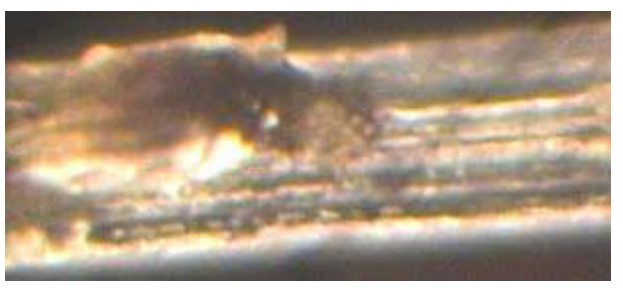

(b)

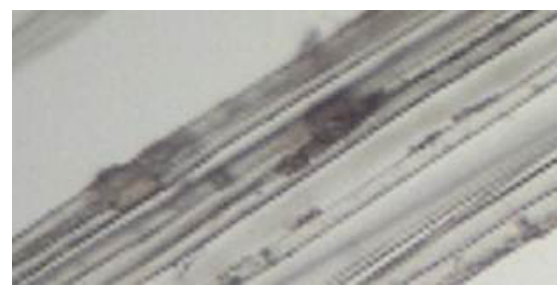

(c)

Figure 3. Deposits of incrusts on the surface $(a, b)$ and woody lignified formations (c) in the structure of bast bundle 
selective splitting of impurity deposits. In this situation delicate middle lamellae suffer significant damage, while solid deposits of incrusts and intercellular formations in the complex fiber remain insufficiently destroyed.

Biochemical methods of nanoengineering of linen textile materials make it possible to successfully solve the task of rational splitting of cellulose companions and improve uniformity of industrial flax fiber breaking during spinning process with a minimum amount of elementarization processes. For this purpose, this research includes a number of studies aimed at justification of the choice of multienzyme systems for the processes of fiber preparation for spinning taking into account the size of the applied enzyme globule and the necessary degree of removal of impurities from fibrous matrix.

\section{Experimental part}

\section{Materials}

The object of this research is roving, whose linear density is 16 tex, made out of combed flax fiber. The enzymatic treatment of fibrous materials was carried out using pectolytic enzyme preparations produced by the biochemical company «Enzyme» CJSC (Ladyzhyn, Vinnytsia oblast, Ukraine) and microbiological producers from the Russian National Collection of Industrial Microorganisms (VKPM) such as Bac. subtilis VKPM B-1093 and microscopic fungi strains Asp. flavus VKPM F-591 strains.

\section{Methods}

The surface of bast fiber bundles was studied using an optical light microscope. The longitudinal surface and cross section of flax fiber were examined through a monocular optical light microscope with magnification of $63 . .1350 \mu \mathrm{m}$. The paraffin sections of flax fiber with a thickness of $30 \mu \mathrm{m}$ cut using a microtome were analyzed.

\section{Analysis of the polysaccharide content in flax fiber}

The content of polysaccharides in the fibrous material was evaluated through their sequential extraction [20]. The pectic substances were extracted by boiling with $1 \%$ citric acid ammonium solution for 2 hours. Then, $30 \mathrm{ml}$ of the filtered extract were mixed with an equal amount of $8 \mathrm{~N}$ solution of $\mathrm{H}_{2} \mathrm{SO}_{4}$, boiled for an hour, neutralized by $8 \mathrm{~N}$ solution of $\mathrm{NaOH}$ and brought up to $100 \mathrm{ml}$. At the second stage, hemicelluloses were extracted by boiling fibers with $2 \% \mathrm{HCl}$ solution. When the filtrate has been neutralized with $\mathrm{Na}_{2} \mathrm{CO}_{3}$ solution using methyl orange as an indicator, the volume was brought up to $500 \mathrm{ml}$. After that, the remaining fibers were crushed in a mortar with $25 \mathrm{ml}$ of $78 \% \mathrm{H}_{2} \mathrm{SO}_{4}$ solution for 60 minutes. The resulting mass was transferred into a flask with hot water and its volume was brought up to $100 \mathrm{ml}$. The mixture was boiled for an hour and, after the mixture has been cooled, the coagulated lignin was filtered for the subsequent gravimetric assessment of its content. For the differentiated determination of pectin and hemicelluloses, the filtrates of polysaccharides obtained through sequential extraction were subjected to spectrophotometric analysis using polymer/o-toluidine colored complex [21].

\section{Methods of selective extraction treatment of blended flax roving}

Methods of selective extraction treatment of blended flax roving samples with different degrees of hardness were used for the differentiated assessment of effect of polymer cellulose companions on fiber spinnability and yarn properties. The content of the extracted component was variable while the mass fraction values of other polymer flax cellulose companions remained constant. These values are given in Table 1.

After the selective removal of impurities and the yarn formation, a number of samples of fibrous materials were analyzed. The content of extracted component (pectin, lignin) was changed by increasing duration of exposure to extracting agents for up to $120 \mathrm{~min}$ with $20 \mathrm{~min}$ intervals. To extract pectic substances from fiber, the samples were processed with a solution of the homogeneous enzyme preparation (pectin-lyaze) at $40 \pm 0,2^{\circ} \mathrm{C}$. Lignin impurities were extracted using dioxane at $80 \pm 0,2^{\circ} \mathrm{C}$. The selective removal of hemicelluloses was carried out with acetate buffer solution with $\mathrm{pH} 4,0$ at $95 \pm 0,1^{\circ} \mathrm{C}$ after fiber samples processing for $6,12,18,24$ and 30 hours. After the selection of fiber for polymer composition analysis, the received samples of roving were subjected to wet spinning under the equal conditions of spinning machine operation.

Table 1. The variability of the composition of extracted component was obtained under controlled constant mass fraction values of other polymer flax cellulose companions

\begin{tabular}{|c|c|c|c|}
\hline \multirow{2}{*}{$\begin{array}{c}\text { Extractable } \\
\text { component }\end{array}$} & $\begin{array}{c}\text { Non-extractable } \\
\text { cellulose companions }\end{array}$ & \multicolumn{2}{|c|}{$\begin{array}{c}\text { Content of non-extractable polymeric impurities (wt. \%) in flax roving } \\
\text { samples }\end{array}$} \\
\cline { 2 - 4 } & pectin & medium soft fiber & coarse fibers \\
\hline \multirow{2}{*}{ hemicellulose } & lignin & $3,9 \pm 0,05$ & $5,6 \pm 0,05$ \\
\cline { 2 - 4 } & hemicellulose & $5,2 \pm 0,05$ & $6,9 \pm 0,05$ \\
\hline \multirow{2}{*}{ pectin } & lignin & $12,1 \pm 0,05$ & $16,1 \pm 0,05$ \\
\cline { 2 - 4 } & pectin & $5,2 \pm 0,05$ & $6,9 \pm 0,05$ \\
\hline \multirow{2}{*}{ lignin } & hemicellulose & $3,9 \pm 0,05$ & $5,6 \pm 0,05$ \\
\cline { 2 - 4 } & & $12,1 \pm 0,05$ & $16,1 \pm 0,05$ \\
\hline
\end{tabular}




\section{Analysis of size of pectin-degrading enzymes particles in hydrosols}

The analysis of size of pectin-degrading enzymes particles in hydrosols was carried out using electro-optical method of dynamic light scattering (DLS) [22]. The measurements were collected using a Zetasizer Nano ZS. The aqueous solutions of enzyme preparations were analyzed at $22 \pm 0,1^{\circ} \mathrm{C}$ for $5 . .10 \mathrm{~min}$. The distilled water with a dispersion index of 1,33 at $\mathrm{T}=22^{\circ} \mathrm{C}$ was used as the basis of comparison. In accordance with the literature sources, the following parameters were taken relating to the enzyme preparation: refractive index - 1,44; absorbance ration at $630 \mathrm{~nm}-0,10$. When using system monitoring software by Malvern Instruments LTD, the particles were assumed to be spherical taking into account that, currently, the structure of pectolytic enzymes molecules is presented in the form of randomly folded tangle.

\section{Analysis of activity of solutions of pectolytic preparations}

The activity of solutions of pectolytic preparations was evaluated in relation to $1 \%$ solution of model substrates using the following methods [23]:

- pectinesterase activity (PE, unit/ml) - evaluating the amount of the liberated carboxylic groups on the basis of measurement of the speed of esters hydrolysis in a macromolecule of high methoxylated apple pectin; after an hour-long fermentation of substrate, the potentiometric titration of $0,1 \mathrm{~N}$ using $\mathrm{NaOH}$ solution was performed;

- endopolygalacturonase activity (PGendo, unit/ml) - evaluating the decrease in viscosity of polygalacturonic acid testing solution; the viscosity of a reaction mixture was evaluated using a viscometer VPZ-2 thermostated at $30 \pm 0,1^{\circ} \mathrm{C}$ with a capillary diameter of $0,8 \mathrm{~mm}$;

- activity of exogenous enzymes (PGexo, unit/ml) - evaluating the increase in the number of terminal aldehyde groups during enzymatic degradation of polygalacturonic acid using the method of back titration with sodium thiosulfate solution.

\section{Enzymatic treatment}

Enzymatic treatment of flax fiber materials was carried out with a solution of enzyme preparations at $40 \pm 0,1^{\circ} \mathrm{C}$, with $\mathrm{pH} 6,5$ and bath module $1: 10$ for $t_{f}=1 \ldots 3 \mathrm{~h}$ with subsequent wash with a solution of detergent and water.

\section{Peroxide treatment}

The subsequent peroxide treatment of roving samples requires the following conditions:

- content of solution components: $5,5 \mathrm{~g} / \mathrm{l}$ of $\mathrm{NaOH}, 5 \mathrm{ml}$ of 11,61 $\mathrm{M} \mathrm{H}_{2} \mathrm{O}_{2}$ for $1 \mathrm{~kg}$ of roving; $0,6 \mathrm{~g} / \mathrm{l}$ of peroxide stabilizer;

- heating from 40 to $95 \pm 0,1^{\circ} \mathrm{C}$;

- exposure at $95 \pm 0,1^{\circ} \mathrm{C}$ for 45 minutes.

\section{Alkaline-peroxide bleaching}

The alkaline-peroxide bleaching applied by the Italian Corporation "Unificio \& Canaprfido Nazionale» was used for comparison. This method includes a stage of fiber alkaline pulping at $95 \pm 0,1^{\circ} \mathrm{C}$ for 50 minutes. The technological solution contains $5 \mathrm{~g} / \mathrm{l}$ of $\mathrm{Na}_{2} \mathrm{CO}_{3}, 5 \mathrm{~g} / \mathrm{l}$ of $\mathrm{NaOH}$ and a wetting agent on the basis of ionic and nonionic surfactants. After the implementation of this method, the peroxide fiber treatment was performed in accordance with the above specified conditions.

\section{Spinning process of rove}

The spinning process of roving prepared using the above mentioned methods was carried out through wet method under comparable conditions in the spinning machine with the following operational parameters: number of spindles revolutions - 5300 rpm; distance between pulling devices - $150 \mathrm{~mm}$; increase in the length of complexes (stretch) - 11,1; number of twists (twist) - 420 twists $/ \mathrm{m}$. In accordance with the process parameters, the yarn was produced with a nominal linear density of 56 tex.

Geometric, deformation and strength characteristics of the resulting flax yarn were tested using known methods of textile material science [24].

\section{Mathematical processing of the total of experimental data}

The mathematical processing of the set of experimental data was performed using statistical methods, cluster, correlation, and regression analysis. The "composition-property" models for the description of the efficiency of processes of textile materials biomodification were elaborated using the mathematical apparatus of multivariate linear regressions on the basis of the Statgraphics PLUS 2000 Professional software.

\section{Results and Discussion}

The optimal content of polymer components in flax fiber during spinning was identified at the first stage of research to justify the originality of techniques of nanostructural modification of flax materials. Two types of roving formed respectively from fiber of medium softness (with $28 \%$ of coarse flax fiber added to the mixture) and of higher hardness (containing $35 \%$ of coarse flax fiber) were selected for testing. Figure 4 presents the results of the study of separate and cumulative influence of pectic substances $(P)$, hemicellulosic compounds $(\mathrm{HC})$ and lignin $(L)$ during their selective removal from roving on the change of values of linear density $\left(T_{p r}\right.$, tex), flexibility $\left(G_{p r}, m m\right)$ and breaking load $\left(\mathrm{P}_{\mathrm{o}}, \mathrm{CH} / \mathrm{tex}\right)$ of yarn experimental samples. The values of the non-extractable fraction of polymeric impurities in flax roving samples, while varying the extractable components content, are given in Table 1.

Data presented in Figure 4a confirm that the residual content of lignin and pectic substances is the most crucial characteristic for the increase in efficiency of flax complexes crushing during the spinning process. Within the range of changes of the lignin mass fraction from 7 to $4.5 \%$, the rate of $\mathrm{T}_{\mathrm{pr}}$ index reduction 
attains its maximum and is 2,0 tex/wt.\% (curve $L^{*}$ ). As the residual lignin content decreases to $2 \%$, the rate of $T_{p r}$ index reduction is reduced by half and has almost the same values for the curves $L$ and $L^{*}-1,2$ tex/wt.\%. The extraction of pectic impurities from both types of fibrous material ensures the rate of $\mathrm{T}_{\mathrm{pr}}$ reduction at 1.3 tex/wt.\%. In this context, the selective extraction of hemicellulosic compounds has a significant influence only if their content exceeds $10 \mathrm{wt} . \%(0,8 \ldots 1,0$ tex/ wt.\%) as a result of the destruction of the majority of incrusting residues of stem parenchyma tissue on the outer surface of the complexes. However, the destruction of hemicellulose in the structure of intercellular formations of complex fiber (less than 10 wt.\%) has an insignificant influence on the yarn fineness (the rate of $\mathrm{T}_{\mathrm{pr}}$ value reduction does not exceed 0.18 tex/wt.\%).

The analysis of the influence of flax cellulose polymer companions on the yarn flexibility (see Figure 4b) demonstrates the extreme dependence from the content of hemicelluloses. Moreover, the maximum point in the curve $G_{p r}=f(H c)$ coincides with the area of the kink in the curves of semi-finished product linear density change. Thus, it can be assumed that the destruction of such type of impurities in incrusts has beneficial effects and the extraction of hemicelluloses from intercellular formations can degrade the deformation properties and fiber twistability. The removal of lignin from fiber has a determining influence on the change in yarn flexibility. Moreover, the dynamic of $G_{p r}$ value changes rises significantly when the residual lignin content is less than 4 wt.\% due to its effective removal from intercellular lignifications. The yarn flexibility also increases upon the selective destruction of pectic substances; however, the achieved rate of increase is minimal and inferior to the efficiency of lignin removal by $2,3 \ldots 3,2$ times. If the pectin content is $0,5 \mathrm{wt} . \%$ or less, the value of $\mathrm{G}_{\mathrm{pr}}$ stops increasing.

The concentration dependences of the change in yarn breaking load (see Figure 4c) when extracting the analyzed types of flax cellulose polymer companions, are extreme. Obviously, the presence of the threshold limit value for the dependencies of yarn strength on pectin content is determined by the necessity of the presence of a certain quantity of pectic substances in the fibrous material to ensure adhesion of crushed complexes in the dried yarn structure. For both types of original raw flax material, the semi-finished product strength attains its maximum value when the range of pectin mass fraction in the yarn is from 1,5 to $0,5 \mathrm{wt} . \%$. The position of the optimal $P_{\text {o }}$ value in the concentration curves for the hemicelluloses content is set up in accordance with the same dependencies as for the above discussed yarn quality parameters. The increase in yarn breaking load, when reducing the lignin content in the fiber, should be considered as a result of more uniform crushing of flax complexes and reduced number of thin spots able to accumulate the effects of external stresses. Besides, the observed decrease in Po value, when the residual lignin content is less than $2 \mathrm{wt}$ \%, can be provoked by deterioration of longitudinal butt joints of elementary fibers.

The "composition-property" dependencies were identified after the mathematical processing of experimental data. They describe the relationship between physical and mechanical properties of the yarn and residual content of flax cellulose polymer companions:

$\mathrm{T}_{\mathrm{pr}}=52,946+0,319 \mathrm{P}+0,0002 \mathrm{P}^{2}+0,835 \mathrm{~L}+0,003 \mathrm{~L}^{2}+0,105 \mathrm{Hc}$ $+0,013 \mathrm{Hc}^{2} ; \mathrm{R}=0,928$,

$$
\begin{aligned}
& G_{p r}=33,446+10,20 L-5,667 L^{2}+3,908 H c-0,521 H^{2}-0,650 P \\
& -0,059 P^{2} ; R=0,979,
\end{aligned}
$$

a)

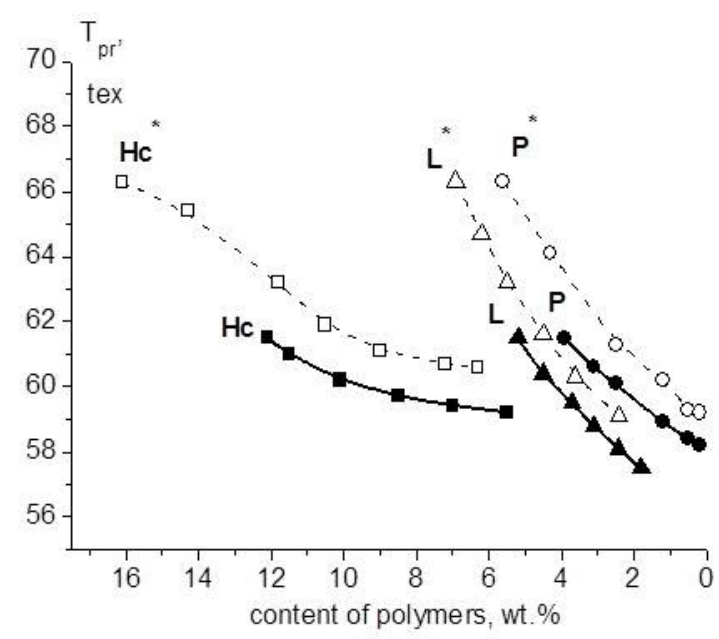

b)

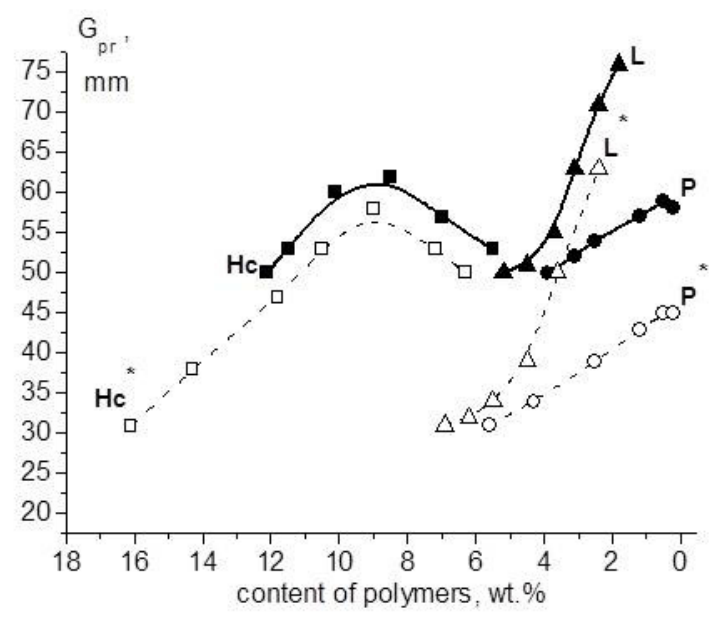

c)

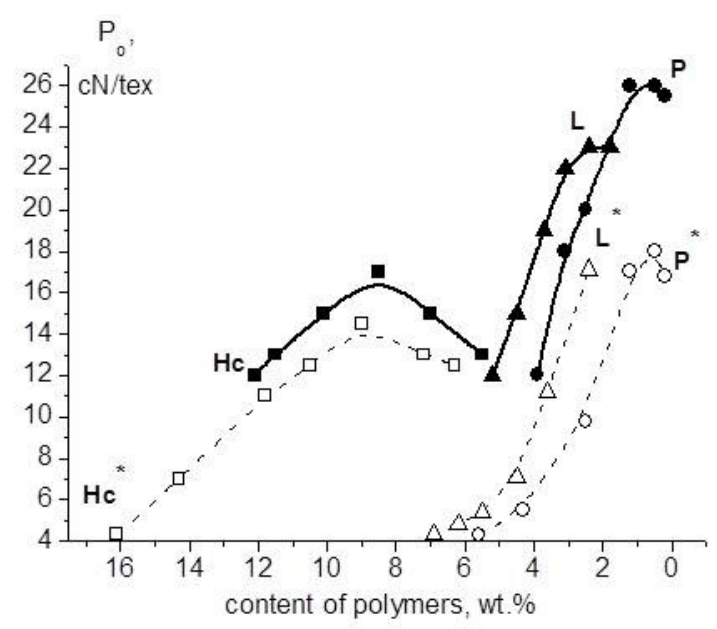

Figure 4. The change of yarn linear density (a), flexibility (b) and breaking load (c) during the selective extraction of hemicellulosic compounds, pectic substances and lignin from blended roving of medium softness $(\mathrm{Hc}, \mathrm{P}$, and $\mathrm{L})$ and higher hardness $\left(\mathrm{HC}^{*}, \mathrm{P}^{*}\right.$, and $\left.\mathrm{L}^{*}\right)$ 
$P_{\circ}=19,800+0,559 P-1,398 P^{2}+3,402 L-1,512 L^{2}+0,751 H c$ $-0,083 \mathrm{Hc}^{2} ; \mathrm{R}=0,912$.

The efficiency of the received model was verified on the basis of the data in literature and the results of the authors' study of polymer composition and controlled properties of yarn made from chemically prepared roving. The application of the elaborated "composition-property" dependencies allows an adequate description of the new set of data. The deviations of experimental results from the calculated values do not exceed $3 \%$.

The solution of the presented system of equations has allowed identifying the ranges of the optimal values of the residual content of impurities in the fiber prepared for spinning (wt.\%): pectin $-0,35 \ldots 0,45$; lignin $-2,0 \ldots 2,5$; hemicellulose $-7,0 \ldots 8,0$.

The biochemical methods of polymer content modification have been elaborated in order to obtain the optimal values of polymers content in flax fiber. These methods ensure the achievement of effects of textile materials nanoengineering by means of spatially localized selective influence of protein catalysts on certain types of polymer impurities structures. The size of biocatalyst molecules is a tool for achieving the necessary structural level of flax complexes modification. The experimental assessment of size has become possible due to the elaboration of methods of hydrosol nanoparticles size analysis.

Figure 5 shows the curves of distribution of the light scattering intensity (I) by particles size ( $r$ ) for pectinase preparations of two microbiological producers: Bac. subtilis VKPM B-1093 n Asp. flavus VKPM F-591.

The presented data clearly demonstrate that isoforms of pectolytic enzymes, whose globules has a huge variation in size, are obtained due to varying microbial producers and conditions of their cultivation. Thus, a sample of enzyme preparation produced by Bac. subtilis strain has a molecule size of $50 \ldots 100 \mathrm{~nm}$. In this case, the maximum value of light scattering intensity corresponds to the value $r=80 \mathrm{~nm}$. Asp. flavus generates enzymes whose globule size is $4 \ldots 8 \mathrm{~nm}$.

The differences in enzyme sizes predetermine the possibility of manifestation of their catalytic activity only in the areas of fibrous material available for the penetration of protein molecules and the spatial orientation of their active center in relation to complementary spots of the fragmented substance macromolecule. This opens up new possibilities for the control of polymer composition and fiber structure in accordance with the required technological and consumer parameters of textile materials.

The technological efficiency of application of the analyzed groups of multienzyme compositions, whose globule size is respectively $4 \ldots 8 \mathrm{~nm}$, was verified during the process of flax fiber modification. The most suitable composition was chosen on the basis of comparative analysis of the results of bast bundles surface assessment using an optical light microscope, as well as physical and chemical properties of biomodified roving and yarn. Microscopic pictures of bast bundle before and after enzyme treatment are shown in Figure 6.

The comparative analysis of the pictures in Figure $6 a$ and $6 \mathrm{~b}$ indicates that protein catalytic systems, whose molecule size is less than $10 \mathrm{~nm}$, like chemical agents, provoke the destruction of polymers in all fiber structural areas. It should be noted that thin middle lamella degrade considerably, while massive deposits of incrusts and intercellular formations in complex fiber structure are not completely broken. As a consequence, the process is accompanied by separation of a significant number of elementary fibers from a bundle, and that leads to the loss of raw materials along with feather waste of spinning production. The similar results are obtained when applying traditional methods of flax roving treatment using chemical agents.

Thus, it is preferable to use enzymes whose globules size is $50 \ldots 100 \mathrm{~nm}$ (see Figure 6c) when preparing roving for

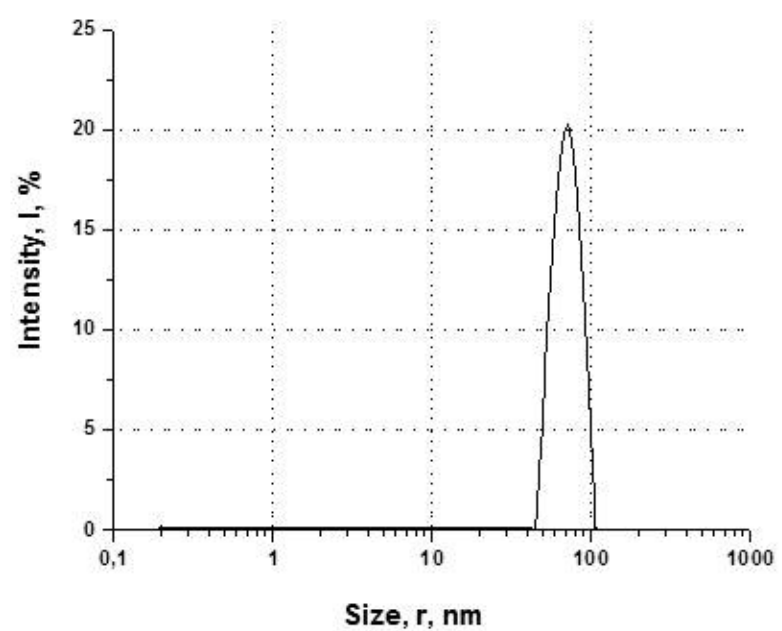

(a)

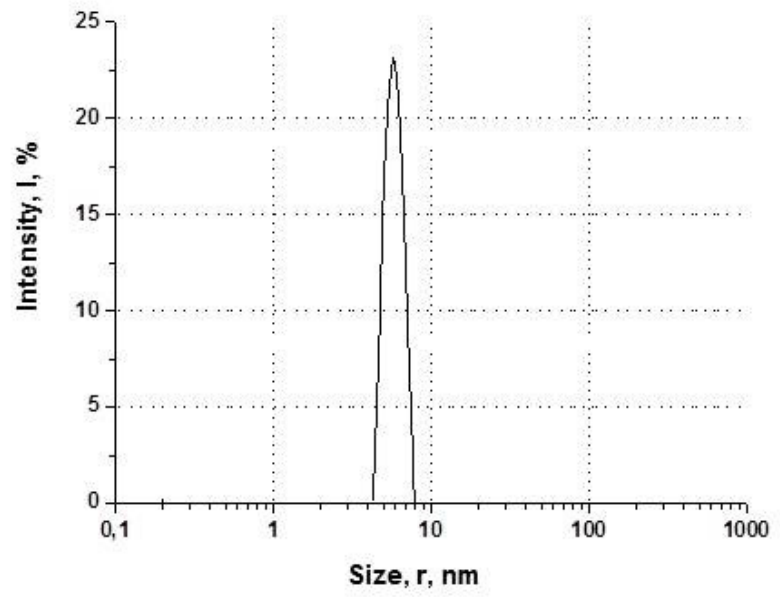

(b)

Figure 5. Distribution of size of protein globules of pectin-degrading enzymes produced by bacterial strains Bac. subtilis (a) and Asp. flavus (b) 


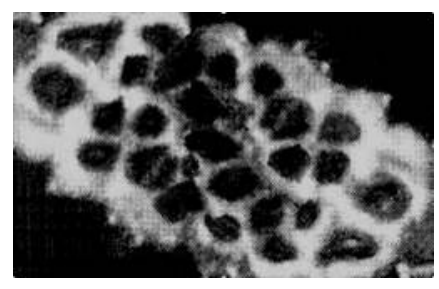

(a)

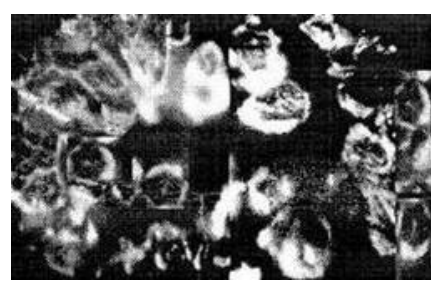

(b)

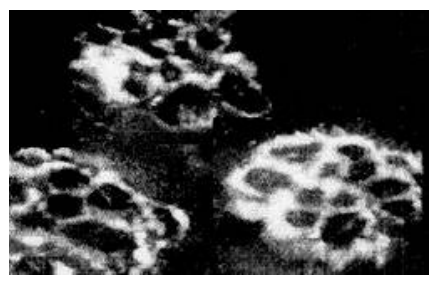

(c)

Figure 6. Efficiency of bast bundle break-down (a) after enzymatic treatment by enzymes whose molecules size is $4 \ldots 8 \mathrm{~nm}$ (b) and $50 \ldots 100 \mathrm{~nm}$ (c)

spinning. In this case, the process of biocatalytic destruction of impurities is spatially limited only by the areas of massive intercellular formations and surface incrusts [25]. The presence of steric difficulties predetermines the impossibility of influence of enzymes on nanosized structural elements that are technologically necessary for a quality spinning. It helps ensure high level of uniformity of industrial flax fiber crushing during spinning and minimal level of elementarization.

The quantitative assessment of the efficiency of bast bundle structural elements destruction, when applying biocomposites containing enzymes whose globules size is $50 \ldots 100 \mathrm{~nm}$, was performed in accordance with the results of the analysis of the degree of impurities extraction from flax fiber. Table 2 presents the results of model experiments of preparation of roving made from soft fibers, medium-soft and coarse flax fibrous raw materials. Taking into account that recommendations relating to the use of biocatalysis during the process of flax fiber preparation for spinning propose the consequential realization of stages of enzymatic treatment and bleaching by alkalineperoxide solutions, the data analysis was carried out taking into consideration the differentiation of the enzyme and peroxide treatment contribution to the process of cellulose polymeric companions extraction. It helped to identify ways of control of the destructive effect intensity for each flax fiber component.
Such control is an objective necessity for improvement of biochemical technology of materials nanoengineering.

The observation of the changes in polyuronides mass fraction between stages and at the end of the enzymatic-peroxide fiber preparation allows to make a conclusion that increase in degree of removal of such type of impurities during roving bleaching is $0,6 \ldots 0,8 \mathrm{wt} \%$. Therefore, in order to ensure the final residual content of pectin at the above recommended level, the pectin degradation level at the stage of enzymatic treatment should attain the intermediate value of $P_{1}=1,0 \pm 0,1 \mathrm{wt}$. \%.

Increased enzymatic destruction of polyuronide component of binders helps to increase the degree of neutral polysaccharides extraction. Moreover, in the case of high values of their initial content, a significant desorption has been observed already at the stage of biological treatment. Apparently, it can be explained by weakened adhesion in incrusting formations on the flax complexes surface and their removal during wash process. Besides, their mass fraction reduction at the stage of peroxide treatment is retarded due to the effect known from the literature source [26], i.e. inhibition of hydrolysis of polysaccharides in the presence of the oxidant. The $\mathrm{Hc}_{1} / \mathrm{Hc}_{2}$ relation is less than $1,4 \ldots 1,6$ times and the residual content of hemicelluloses is close to the optimal value.

Table 2. The influence of the conditions of enzymatic treatment on interstage and final change of the composition of polymeric impurities in flax fiber roving samples

\begin{tabular}{|c|c|c|c|c|c|c|c|c|c|c|c|c|c|}
\hline \multirow{3}{*}{ Fiber type } & \multirow{2}{*}{\multicolumn{3}{|c|}{$\begin{array}{l}\text { Initial content of } \\
\text { polymers, wt.\% }\end{array}$}} & \multirow{2}{*}{\multicolumn{3}{|c|}{$\begin{array}{c}\text { Activity of enzymes } \\
\text { of pectolytic complex, } \\
\text { units } / \mathrm{ml}\end{array}$}} & \multirow{3}{*}{$\begin{array}{c}\mathbf{t}_{\mathrm{f}}, \\
\min \end{array}$} & \multicolumn{6}{|c|}{ Residual content of polymers, wt. $\%$} \\
\hline & & & & & & & & \multicolumn{3}{|c|}{$\begin{array}{c}\text { after enzyme } \\
\text { treatment }\end{array}$} & \multicolumn{3}{|c|}{$\begin{array}{l}\text { after peroxide } \\
\text { treatment }\end{array}$} \\
\hline & $\mathbf{P}_{0}$ & $\mathrm{Hc}_{0}$ & $\mathbf{L}_{0}$ & PE & $P G_{\text {endo }}$ & $P G_{\text {exo }}$ & & $\mathbf{P}_{1}$ & $\mathrm{Hc}_{1}$ & $\mathrm{~L}_{1}$ & $\mathbf{P}_{2}$ & $\mathrm{Hc}_{2}$ & $\mathrm{~L}_{2}$ \\
\hline \multirow{3}{*}{ soft } & \multirow{3}{*}{2,8} & \multirow{3}{*}{10,1} & \multirow{3}{*}{3,7} & \multirow{3}{*}{0,80} & \multirow{3}{*}{20,0} & \multirow{3}{*}{0,20} & 60 & 1,97 & 10,0 & 3,7 & 1,29 & 7,9 & 2,9 \\
\hline & & & & & & & 90 & 1,44 & 9,9 & 3,6 & 0,81 & 7,5 & 2,7 \\
\hline & & & & & & & 120 & 0,96 & 9,9 & 3,6 & 0,36 & 7,1 & 2,0 \\
\hline \multirow{4}{*}{ medium-soft } & \multirow{4}{*}{3,9} & \multirow{4}{*}{12,1} & \multirow{4}{*}{4,2} & \multirow{4}{*}{1,20} & \multirow{4}{*}{22,5} & \multirow{4}{*}{0,25} & 60 & 2,18 & 12,0 & 4,2 & 1,41 & 9,8 & 3,5 \\
\hline & & & & & & & 120 & 1,53 & 12,0 & 4,2 & 0,85 & 9,4 & 3,0 \\
\hline & & & & & & & 150 & 1,27 & 11,4 & 4,2 & 0,64 & 8,7 & 2,7 \\
\hline & & & & & & & 180 & 1,01 & 11,0 & 4,2 & 0,39 & 7,8 & 2,5 \\
\hline \multirow{4}{*}{ coarse } & \multirow{4}{*}{5,6} & \multirow{4}{*}{16,1} & \multirow{4}{*}{6,9} & \multirow{4}{*}{3,40} & \multirow{4}{*}{24,9} & \multirow{4}{*}{0,35} & 60 & 2,96 & 15,9 & 5,6 & 2,13 & 11,2 & 4,7 \\
\hline & & & & & & & 120 & 2,01 & 15,8 & 5,6 & 1,24 & 10,9 & 4,2 \\
\hline & & & & & & & 150 & 1,57 & 14,8 & 5,5 & 0,85 & 9,7 & 3,8 \\
\hline & & & & & & & 180 & 1,12 & 14,2 & 5,5 & 0,45 & 8,9 & 3,5 \\
\hline
\end{tabular}


The enzymatic treatment does not change the lignin content in fiber but contributes to increasing its accessibility for agents at the oxidation treatment stage and the degree of its extraction from fibrous material by 1,4 times. During the processing of roving made from soft fiber and raw materials of moderate softness, the achieved effect of delignification, estimated 1,7 wt. $\%$, decrease in the mass fraction, can be sufficient to ensure the quality fiber crushing during spinning.

As a result of stage-wise estimation of the change in polymeric composition of flax fiber for technological option of biochemical preparation of roving for spinning, involving enzymatic treatment in addition to traditional peroxide treatment, the following preferable values of the residual content of cellulose polymer companions after biological treatment (wt. \%) can be recommended: pectin $1,0 \pm 0,1$; lignin $-3,9 \pm 0,3$; hemicellulose $-11,0 \pm 1,0$. Depending on the type of processed raw material and used profiles of enzyme activity, the effect of multienzyme compositions, whose globule size is $50 \ldots 100 \mathrm{~nm}$, ensures obtaining the necessary level of impurities extraction within $120 \ldots 180$ minutes.

The result of selective spatially localized effect of enzymes in the fiber structure is reflected by increase in uniformity of flax complexes crushing during spinning. It is clearly demonstrated by the Table 3 presenting the full set of characteristics of structural, physical and mechanical as well as deformation properties of yarn samples made from chemically prepared and biomodified flax fiber.

Table 3. Quality parameters of yarn from roving with addition of coarse fiber after the preparation using chemical and biochemical modes

\begin{tabular}{|c|c|c|c|c|c|c|c|}
\hline \multirow{5}{*}{ № } & \multirow{5}{*}{ Characteristics of yarn } & \multicolumn{6}{|c|}{ Value of parameters for roving samples made from heckled fiber } \\
\hline & & \multicolumn{3}{|c|}{ medium-soft coarse } & \multicolumn{3}{|c|}{ coarse } \\
\hline & & \multicolumn{6}{|c|}{ After } \\
\hline & & \multirow{2}{*}{$\begin{array}{l}\text { Chemical } \\
\text { treatment }\end{array}$} & \multicolumn{2}{|c|}{ Biochemical treatment } & \multirow{2}{*}{$\begin{array}{l}\text { Chemical } \\
\text { treatment }\end{array}$} & \multicolumn{2}{|c|}{ Biochemical treatment } \\
\hline & & & $4 . .8 \mathrm{~nm}$ & $\begin{array}{c}50 \ldots 100 \\
\mathrm{~nm}\end{array}$ & & $4 \ldots 8 \mathrm{~nm}$ & $\begin{array}{c}50 . . .100 \\
\mathrm{~nm}\end{array}$ \\
\hline 1 & Linear density, tex & 54,0 & 53,6 & 51,0 & 58,9 & 56,2 & 53,6 \\
\hline 2 & $\begin{array}{l}\text { Thickness, average diameter } \\
\qquad \mathrm{d}_{\mathrm{av}}, \mathrm{mm}\end{array}$ & 0,38 & 0,36 & 0,30 & 0,35 & 0,32 & 0,29 \\
\hline 3 & $\begin{array}{c}\text { Linear density coefficient of } \\
\text { variation, } \%\end{array}$ & 7,2 & 7,1 & 4,2 & 10,8 & 9,5 & 6,4 \\
\hline 4 & $\begin{array}{c}\text { Number of defects by } 100 \mathrm{~m} \text { of } \\
\text { yarn: } \\
\text { - thick spots exceeding } 1,5 \mathrm{~d}_{\mathrm{av}} \\
\text { - thin spots, less than } 0,7 \mathrm{~d}_{\mathrm{av}}\end{array}$ & $\begin{array}{l}280 \\
433\end{array}$ & $\begin{array}{l}268 \\
408\end{array}$ & $\begin{array}{l}108 \\
183\end{array}$ & $\begin{array}{l}412 \\
400\end{array}$ & $\begin{array}{l}392 \\
387\end{array}$ & $\begin{array}{l}201 \\
123\end{array}$ \\
\hline 5 & Yarn twist & 537 & 544 & 550 & 540 & 548 & 557 \\
\hline 6 & Twist coefficient & 41,2 & 41,0 & 40,3 & 41,5 & 41,5 & 41,8 \\
\hline 7 & $\begin{array}{l}\text { Coefficient of variation for yarn } \\
\text { twist, } \%\end{array}$ & 8,5 & 8,4 & 7,4 & 9,4 & 9,5 & 7,3 \\
\hline 8 & Breaking strength, cN/tex & 18,9 & 19,1 & 20,5 & 16,4 & 16,6 & 19,8 \\
\hline 9 & $\begin{array}{l}\text { Variation coefficient for breaking } \\
\text { strength, } \%\end{array}$ & 21,1 & 20,9 & 11,5 & 27,8 & 27,5 & 14,4 \\
\hline 10 & Breaking elongation, mm & 8,7 & 9,3 & 11,7 & 6,1 & 6,8 & 9 \\
\hline 11 & Unit toughness, $\mathrm{N}$ cm/g & 417 & 421 & 552 & 393 & 401 & 479 \\
\hline 12 & $\begin{array}{l}\text { Coefficient of variation for unit } \\
\text { toughness, } \%\end{array}$ & 10,4 & 9,8 & 6,2 & 12,5 & 11,9 & 5,7 \\
\hline 13 & $\begin{array}{l}\text { Endurance to repeated bending } \\
\text { and abrasion, cycles }\end{array}$ & 5595 & 6673 & 8049 & 5586 & 6661 & 9738 \\
\hline 14 & $\begin{array}{l}\text { Share of components in relation } \\
\text { to elongation at one-cycle tests, } \\
\% \text { : } \\
\text { - fast recoverable } \Delta_{\mathrm{fr}} \\
\text { slow recoverable } \Delta_{\mathrm{sr}} \\
\text { - residual } \Delta_{\mathrm{r}}\end{array}$ & $\begin{array}{l}0,43 \\
0,12 \\
0,45\end{array}$ & $\begin{array}{l}0,42 \\
0,15 \\
0,43\end{array}$ & $\begin{array}{l}0,41 \\
0,27 \\
0,32\end{array}$ & $\begin{array}{l}0,42 \\
0,12 \\
0,46\end{array}$ & $\begin{array}{l}0,43 \\
0,13 \\
0,44\end{array}$ & $\begin{array}{l}0,44 \\
0,24 \\
0,32\end{array}$ \\
\hline 15 & $\begin{array}{l}\text { Breakage of yarn, break/ } \\
100 \text { spindles per hour }\end{array}$ & 66 & 56 & 37 & 80 & 72 & 44 \\
\hline
\end{tabular}


Compared to two-stage alkaline peroxide treatment, the use of enzyme compositions containing catalysts, whose globule size is $4 \ldots 8 \mathrm{~nm}$, for flax fiber preparation, does not allow ensuring the rational destruction of large formations of polymer binders. As mentioned above (see Figure 6b), the biocatalysts of this group intensify the processes of destruction of thin middle lamella mostly. Thus, larger, and, therefore, less splitted, intercellular formations play the role of structure-forming elements. As a consequence, after fiber modification by enzymes whose size is $4 \ldots 8 \mathrm{~nm}$, the yarn is characterized by high structural irregularity. It is reflected in low values of coefficients of variation for the parameters of linear density and breaking load. The obtained semi-finished product has lower strength properties compared to the yarn formed from roving prcoessed using biocomposite of the second group of enzymes.

The comprehensive improvement of the yarn quality is achieved when using biocatalysts whose size is $50 \ldots 100 \mathrm{~nm}$. In particular, increase in efficiency and uniformity of complex flax fiber crushing is clearly demonstrated. The comprehensive analysis of the data presented in Tables 2, 3 and Figure 6 allows asserting that the observed effects of improvement of bast bundles crushing are the result of the implementation of spatially localized destruction of large micrometer formations of impurity compounds without damaging middle lamella which preserves the connection of elementary fibers in the complexes of smaller thickness. Besides, the improvement of yarn deformation properties and increase in its twist degree were revealed. Such improvement and increase are due to more efficient realization of delignification of flax fiber using the original method developed by the authors and described in detail in the works $[25,27]$. The method is based on the regulation of degree of biocatalized destruction of flax fiber poly-carbohydrates and the application of the resulting products as agents for chemical transformations of lignin and polyphenolic compounds. The peculiarity of this method is that the generation of reducing agents occurs in the area of splitted intercellular formations of industrial fiber. Therefore, their action is primarily aimed at woody lignified formations located in the immediate vicinity. Besides, the targeted destruction of tightly bound netting structures of lignin is performed without damaging lignin-carbohydrate complex of cell wall of elementary fibers and butt joints.

Thus, the implementation of techniques of flax fibers nanostructured biomodification using the composition of enzymes of maceration-delignification actions has allowed obtaining a unique combination of the following yarn properties:

- increase in its fineness, decrease in coefficient of variation for linear density by $1,6 \ldots 1,9$ times, sharp (by up to 4 times) reduction of structural defects with critical values of thick and thin spots;

- increase in strength by $10 \ldots 21 \%$ while reducing coefficient of variation for breaking strength by twice;

- improvement of the deformation capacity in the processes of wet fiber twisting and deformation resistance of the formed yarn to repeated bending, abrasive and tension in the process of weaving;
- decrease in yarn breakages in spinning machines by $1,5 \ldots 2,0$.

\section{Conclusions}

The influence of polymeric impurities from flax fiber on the physical and mechanical properties of the forming yarn was studied. The results confirm the need in dosed removal of impurities. The destruction of micrometer units of binders in the complex structure of the fiber (incrusts and intercellular formations) while limiting of the polymer degradation in nanosized structures of plant cells, butt joints of elementary fibers and in the cell wall is the technological necessity. Furthermore, the technological necessity to preserve a part of neutral polysaccharides in intercellular formations is confirmed.

The range of the optimal polymers residual content in flax fiber prepared for spinning is identified on the basis of the analysis of «composition-properties» equation and differentiation of the contribution of consecutive enzymatic and peroxide treatment stages to the degradation of polymers. The recommended level of residual pectin, lignin and hemicellulose is (wt. \%):

- after enzymatic treatment: $P_{1}=1,0 \pm 0,1 ; \quad L_{1}=3,9 \pm 0,3$; $\mathrm{Hc}_{1}=11,0 \pm 1,0$;

- after peroxide bleaching: $P_{2}=0,4 \pm 0,05 ; \quad L_{2}=2,3 \pm 0,3$; $\mathrm{Hc}_{2}=7,5 \pm 0,5$.

The research has confirmed that the required level of fiber structural modification and the optimal values of residual impurities at the stage of roving preparation for spinning can be achieved by using protein catalysts whose globule size is $50 \ldots 100 \mathrm{~nm}$. The use of these protein catalysts help to break down polymer adhesives in the areas of incrusts and intercellular formations, which hinder fiber crushing, without damaging the nanosized structures.

The proposed enzymatic methods allow exerting selective effect on the structure of lignin. Unlike the action of chemical agents, the use of these methods helps to prevent the destruction of longitudinal lignin-based butt joins of elementary fibers, which increase the risk of transverse rupture of complexes, and lignin-carbohydrate complex in cell walls which provides amorphization and fiber flexibility.

The proposed approach allows to increase significantly the uniformity of structural and physical and mechanical yarn properties. In particular, increase in yarn fineness and strength properties of semi-finished products, as well as improvement of deformation properties and reduction of yarn breakages during the spinning processes are achieved.

\section{Acknowledgements}

We would like to express our sincere gratitude to the Ministry of Education and Science of Russia for providing the financial support for our research within the project part of the 
government contract in the field of scientific activity (contract No. 11.1898-2014/K).

\section{References:}

[1] Buchert, J., Pere, J., Puolakka, A. e. a.: Scouring of cotton with pectinases, proteases, and lipases. Textile Chemist and Colorist, Vol. 32, No. 5, 48-52, ISSN 0040-490X, 2000.

[2] Degani, O., Gepstein, S., Dosoretz, C.G.: Potential use of cutinase in enzymatic scouring of cotton fiber cuticle. Appl. Biochem. Biotechnol., Vol. 102/103, p. 277-289, PMID: 12396130, 2002.

[3] Yu, X.-W., Guan, W.-J., Li, Y.-Q. e. a.: A biological treatment technique for wool textile. Braz. arch. biol. technol., Vol. 48, № 5, p. 342-354, ISSN 1516-8913, 2005.

[4] Bishop, D., Shen, J., Heine, E. e. a.: The use of proteolytic enzymes to reduce wool-fibre stiffness and prickle. J. Text. Inst., Vol. 89, p. 546-553, 1998.

[5] Akin, D. E. Linen Most Useful: Perspectives on Structure, Chemistry, and Enzymes for Retting Flax. Hindawi Publishing Corporation ISRN Biotechnology, Vol. 2013, Article ID 186534, 23 p., http://dx.doi. org/10.5402/2013/186534, 2013.

[6] Sharma, H. S. S.: The role of bacteria in retting of desiccated flax during damp weather. Applied Microbiology and Biotechnology, Vol. 24, №. 6, p. 463-467, 1986.

[7] Sumere, A. F., Sharma, H. S. S.: Analyses of fine flax fibre produced by enzymatic retting. Aspects of Applied Biology, Vol. 28, p. 15-20, 1991.

[8] Adamsen, P. S., Akin, D. E., Rigsby, L. L.: Chelating agents and enzyme retting of flax. Textile Research Journal, Vol. 72, №. 4, p. 296-302, doi: 10.1177/004051750207200404, 2002.

[9] Sharma, H. S. S., Sumere, C. F. e. a.: The Biology and Processing of Flax, M. Publications, Belfast, Ireland, 1992.

[10] Foulk, J. A., Akin, D. E., Dodd, R. B.: Miniature spinning enzyme-retted flax fibers. Journal of Natural Fibers, Vol. 6, №. 1, p. 1-13, ISBN 978-0-9809664-0-4, 2009.

[11] US 20070243596 A1 Simultaneous Desizing and Scouring Process, 2007.

[12] Abdel-Halim, E.S., Fahmy, H.M., Moustafa, M.G.: Bioscouring of linen fabric in comparison with conventional chemical treatment. Carbohydrate Polymers, Vol. 74, $p$. 707-711, DOI: 10.1016/j.carbpol.2008.04.044, 2008.

[13] Buschle-Diller, G., Zeronian, S. H., Pan, N. e. a.: Enzymatic hydrolysis of cotton, linen, ramie, and viscose rayon fabrics. Textile Research Journal, Vol. 64, №. 5, p. 270-279, 1994.
[14] Cheshkova, A. V., Zavadskii, A. E., Loginova V. A.: New Biochemical Approaches to Fiber Modification in the Solution of the Problem of Unifying Cellulose Pretreatment Technologies. Russian Journal of General Chemistry, Vol. 83, No. 1, p. 177-184, DOI: 10.1134/S1070363213010386, 2013.

[15] Ossola, M., Galante, Y. M.: Scouring of flax rove with the aid of enzymes. Enzyme and Microbial Technology, Vol.34, p.177-186, http://dx.doi.org/10.1016/j. enzmictec.2003.10.003, 2004.

[16] Zhang, J., Henriksson, G., Johansson, G.: Polygalacturonase is the key component in enzymatic retting of flax. J. of Biotechnology, Vol. 81, p. 85-89, ISSN 0168-1656, 2000.

[17] Henriksson, G., Akin, D.E. Slomczynski, D. e. a.:Production of highly efficient enzymes for flax retting by Rhizomucor pusillus. Biotechnology J. of Biotechnology, Vol. 68, p. 115-123, ISSN: 0168-1656, 1999.

[18] Abramova, L.I., Berezina, N.A.: Anatomy, morphology and systematics of plants. Moscow State University Press, ISBN 5-211-01855-9, 1990.

[19] Kashayp, D. R., Vohra, P. K., Soni, S. K.: Degumming of buel (Grewia optiva) bast fibres by pectinolytic enzyme from Bacillus sp. DT7 Biotechnol. Lett, Vol. 23, p. 12971301, ISSN: 0141-5492, 2001.

[20] Ivanov, N.A.: Physico-chemical fundamentals of cooking flax, Dissertation doctor. tehn. Sciences, 1989.

[21] Usov, A.I., Yarotskiy, S.V.: Separate determination of hexoses and pentoses using o-toluidine reagent. Proceedings of the Academy of Sciences of the USSR. Chemical series, Vol. 4, p. 877-880, 1974.

[22] Berne, B.J., Pecora, R.: Dynamic Light Scatterin. N.Y. Wiley, 1976.

[23] Ruhlyadeva, A.P., Polygalina, G.V.: Methods for determination of hydrolytic enzymes. Legpischprom, 1981.

[24] Buzov, B. A., Alymenkova, N.D., Petropavlovsky, D. G.: Materials Laboratory workshop on sewing production. Legprombytizdat, 1991.

[25] Aleeva S. V., Koksharov S. A.: Chemistry and Technology of Biocatalyzed Nanoengineering of Linen Textile Materials, Russian Journal of General Chemistry, Vol. 82, No. 13, p. 2279-2293, ISSN: 1070-3632,2012.

[26] Pavasars, I., Hagberg, J., Boren, H. e. a.: Alkaline degradation of cellulose: mechanisms and kinetics. Journal of polymers and environment, Vol.11, No. 2, p. 39-47, ISSN: 1566-2543, 2003.

[27] Lepilova, O.V., Aleeva S.V., Koksharov S. A.: Analysis of chemical transformations of lignin in alkaline solutions of monosaccharides, Chemistry of plant raw materials, No. 1, p. 47-52, DOI: 10.14258/jcprm.1301047, 2013. 